\title{
ENERGY REQUIREMENTS FOR ALLEVIATION OF SUBSOIL COMPACTION AND THE EFFECT OF DEEP TILLAGE ON SUNFLOWER (HELIANTHUS ANNUS L.) YIELD IN THE WESTERN REGION OF ARGENTINA'S ROLLING PAMPA
}

Guido F. Botta ${ }^{1,2,3}$, Diogenes L. Antille ${ }^{4}$, Fernando Bienvenido ${ }^{5}$, David Rivero ${ }^{3}$, Enrique E. Contessotto ${ }^{2}$

${ }^{1}$ Universidad de Buenos Aires, Argentina; ${ }^{2}$ Universidad Nacional de Lujan, Argentina;

${ }^{3}$ Universidad Nacional de La Pampa, Argentina; ${ }^{4}$ CSIRO Agriculture and Food, Australia;

${ }^{5}$ Universidad de Almeria, Spain

gfbotta@agro.uba.ar, dio.antille@csiro.au

\begin{abstract}
Deep tillage is often performed to alleviate traffic-induced subsoil compaction, but how long do the benefits of this technique last for in intensively-managed arable soils? Heavy traffic on loose soil significantly increases the risk of soil re-compaction at depth. Chiselling and subsoiling are techniques commonly used in Argentina to remediate soil/subsoil compaction. Controlled traffic farming (CTF) through the exclusion of heavy vehicles from the field and axle load reduction (e.g., $\leq 6 \mathrm{Mg}$ per axle) is a strategy occasionally used to mitigate compaction impacts. The objectives of this work were to: (a) quantify changes in the physical properties of a medium-textured soil as a result of tillage operations (subsoiling, chiselling) conducted over two consecutive crop seasons, (b) determine the effect of deep tillage on sunflower yield, and (c) quantify fuel consumption and draft requirements of deep tillage on soil affected by compaction. The experiment was conducted at a site located in the western region of the Argentinean Rolling Pampas, which has a loamy Entic haplustoll soil. Experimental treatments consisted of two tillage operations and a control plot, which had been under zero-tillage for more than 8 years. Deep soil loosening was conducted with a $117 \mathrm{~kW}$, FWA tractor as follows: (1) a V-frame 7-shank subsoiler with $35-\mathrm{mm}$ wide and 550-mm long tines. Shanks were spaced at $500 \mathrm{~mm}$ apart, and operated at $450 \mathrm{~mm}$ deep at $5.20 \mathrm{~km} \cdot \mathrm{h}^{-1}$ (2) a chisel plow with 11 rigidly-mounted, curved shanks, spaced at 285-mm apart, and operated at $280-\mathrm{mm}$ deep and $6.12 \mathrm{~km} \mathrm{~h}^{-1}$. The tillage treatments were applied to plots, which were laid-out in a completely randomized block design. This work showed that: (a) the beneficial effects of subsoiling and chiselling on removing soil/subsoil compaction lasted for 2 years, (b) these effects became negligible after that time when traffic intensity was greater than about $95 \mathrm{Mg} \cdot \mathrm{km}^{-1} \cdot \mathrm{ha}^{-1}$ due to re-compaction/re-consolidation of the soil profile, particularly in the 300-600 mm depth interval, and (c) the frequency of subsoiling should be therefore every two years if CTF was not practiced. From agronomic and economic perspectives, the results showed that: (a) sunflower yields were sufficiently high to recover the cost of subsoiling, which cost between 18 and $52 \mathrm{USD} \cdot \mathrm{ha}^{-1}$, (b) in the second year, the yields increases represented a net profit of $12 \mathrm{USD} \cdot \mathrm{ha}^{-1}$, (c) the chisel plow had lower fuel consumption and draft per shank than the subsoiler because of the relative depths at which tines were operated in both units, and (d) the total cross-sectional area loosened by the chisel plow was $14 \%$ higher than that of the subsoiler, but its overall efficiency was about $85 \%$ less compared with the subsoiler.
\end{abstract}

Keywords: chiselling, controlled traffic farming, tillage draft, zero-tillage.

\section{Introduction}

Deep tillage is performed to alleviate traffic-induced subsoil compaction, but how long do the benefits of this technique last for in intensively-managed arable soils? Traffic on loose soil significantly increases the risk of soil re-compaction at depth, and it may therefore aggravate the problem. Soil compaction reduces root growth and therefore exploitation of nutrients and water in the subsoil, which reduces the crop yield [1]. The main arable crops grown in the western Pampas of Argentina are soybeans (Glicyne max. L. Merr.), sunflower (Helianthus annus L.) and maize (Zea mays L.). These crops are particularly susceptible to soil compaction with yield reductions greater than $15 \%$ in most years [2]. Sunflower is South America's fourth most important crop with about 1.6million ha devoted to its production. The main producers of sunflower in this region are Argentina and Paraguay, which together produced about 3.8 million metric tonnes in the 2015/2016 season. Argentina is the second largest exporter of sunflower after Ukraine.

In central east Argentina, sunflower is grown on clayey soils under zero-tillage and these soils are commonly affected by compaction due to traffic with farm machinery. Compaction reduces soil porosity, and has detrimental effects on important soil processes and functions [3;4]. The harmful effects of traffic combined with high axle load and high tyre ground contact pressure on soil properties and crop production are well documented (e.g., [5;6]). Techniques commonly used for remediation and management of soil compaction in that region are chiselling and subsoiling to depths between 280 and $450 \mathrm{~mm}$, and to less extent controlled traffic farming and axle load reduction, respectively [7]. 
Yield responses to chiselling and subsoiling are generally satisfactory, but growers' evidence suggests that the beneficial effects of deep tillage are transient, also noted in related studies [8]. The objectives of this work were to: (a) quantify changes in soil physical properties of an Entic haplustoll as induced by deep tillage (subsoiler and chisel plow) operations conducted over two growing seasons, (b) improve growers' awareness of potential negative effects of field traffic on loose soil following deep tillage operations, (c) determine the effect of deep tillage on sunflower yield, and (d) quantify fuel and draft required to conduct deep tillage operations on this soil.

\section{Materials and methods}

An experiment was conducted in the western region of the Argentinean Rolling Pampa in the province of La Pampa. The soil was a loamy Entic haplustoll [9], with organic matter contents ranging from $2.4 \%$ in the top $100 \mathrm{~mm}$ of the profile to $1.3 \%$ at $600 \mathrm{~mm}$ depth. The experimental site $\left(36^{\circ} 04^{\prime} 33.18^{\prime \prime} \mathrm{S}, 62^{\circ} 29^{\prime} 14.57^{\prime \prime} \mathrm{W}\right)$ is well-drained and had moderate permeability. Surface runoff is negligible on 0 to $1 \%$ slopes, low on 1 to $5 \%$ slopes, and moderate on 5 to $8 \%$ slopes, respectively. Soil cone index $(0-600 \mathrm{~mm})$ before deep tillage indicated the presence of a densified layer between 150 and $300 \mathrm{~mm}$ depth $(1.85 \pm 0.082 \mathrm{MPa})$. A general characterization of the soil at the site was conducted prior to the experiment (Table 1).

Table 1

Soil profile characteristics of Entic haplustoll

\begin{tabular}{|l|c|c|c|c|}
\hline \multicolumn{1}{|c|}{ Soil horizons } & $\mathbf{A}_{\mathbf{p}}$ & $\mathbf{A}_{\mathbf{1 2}}$ & ac & c \\
\hline Depth interval, $\mathrm{mm}$ & $0-120$ & $150-300$ & $350-650$ & $710-1200$ \\
\hline Organic carbon, $\mathrm{g} \cdot \mathrm{kg}^{-1}$ & 12.3 & 6.7 & 5 & - \\
\hline Total nitrogen, $\mathrm{g} \cdot \mathrm{kg}^{-1}$ & 1.5 & 0.8 & 0.7 & - \\
\hline C/N ratio & 8 & 8 & 7 & - \\
\hline Clay $(<2 \mu \mathrm{m}), \mathrm{g} \cdot \mathrm{kg}^{-1}$ & 161 & 284 & 184 & 63 \\
\hline Silt $(2-20 \mu \mathrm{m}), \mathrm{g} \cdot \mathrm{kg}^{-1}$ & 98 & 63 & 76 & 99 \\
\hline Silt $(2-50 \mu \mathrm{m}), \mathrm{g} \cdot \mathrm{kg}^{-1}$ & 176 & 144 & 131 & 206 \\
\hline Very fine sand $(74-100 \mu \mathrm{m}), \mathrm{g} \cdot \mathrm{kg}^{-1}$ & 402 & 302 & 398 & 367 \\
\hline Fine sand $(100-250 \mu \mathrm{m}), \mathrm{g} \cdot \mathrm{kg}^{-1}$ & 159 & 201 & 207 & 261 \\
\hline Medium sand $(250-500 \mu \mathrm{m}), \mathrm{g}^{-1} \mathrm{~kg}^{-1}$ & 4 & 6 & 4 & 4 \\
\hline $\mathrm{pH}$ & 6.1 & 6.1 & 6.3 & 6.7 \\
\hline $\mathrm{pH}$ in $\mathrm{H}_{2} 0(1: 2.5)$ & 6.4 & 6.6 & 6.9 & 6.9 \\
\hline $\mathrm{Ca}{ }^{2+}, \mathrm{meq} \cdot \mathrm{kg}^{-1}$ & 68 & 69 & 77 & 59 \\
\hline $\mathrm{Mg}^{2+}, \mathrm{meq} \cdot \mathrm{kg}^{-1}$ & 13 & 19 & 10 & 20 \\
\hline $\mathrm{Na}^{+}, \mathrm{meq} \cdot \mathrm{kg}^{-1}$ & 2 & 4 & 4 & 3 \\
\hline $\mathrm{K}^{+}, \mathrm{meq} \cdot \mathrm{kg}$ & 20 & 15 & 15 & 10 \\
\hline
\end{tabular}

The following measurements were conducted: draft, fuel consumption, work rate, cone index, sunflower yield, and root dry matter per plant. The treatments consisted of two different deep loosening operations and a no-tillage control plot, which had been in direct sowing for 8 years. Deep loosening was conducted with a $117 \mathrm{~kW}$, FWA tractor as follows: (1) A V-frame 7-shank subsoiler with $35 \mathrm{~mm}$ wide and $550 \mathrm{~mm}$ long tines. Shanks were spaced at $500 \mathrm{~mm}$ apart and operated at $450 \mathrm{~mm}$ deep at a speed of $5.20 \mathrm{~km} \cdot \mathrm{h}^{-1}$, (2) A chisel plow with 11 rigidly-mounted, curved shanks (dimensions: $25 \times 20-\mathrm{mm}$ ), spaced at $285 \mathrm{~mm}$ apart, and operated at $280 \mathrm{~mm}$ deep at a speed of $6.12 \mathrm{~km} \cdot \mathrm{h}^{-1}$. The tillage treatments were applied to all plots (dimensions: $50 \mathrm{~m}$ long by $30 \mathrm{~m}$ wide), which were laid-out in a completely randomized block design with three replications $(n=3)$. After 6 weeks the traffic was applied randomly as required by the sowing operation, but its intensity matched $95 \mathrm{Mg} \cdot \mathrm{km}^{-1} \cdot \mathrm{ha}^{-1}$, which is common in this region where sunflower is grown. Statistical analyses were undertaken with Statgraf and involved analysis of variance (ANOVA) and the Duncan's multiple range test to analyse the means. Linear regression analyses were conducted with GenStat $16^{\text {th }}$ Edition (VSN International Ltd.). 


\section{Results and discussion}

The results are shown in Tables 2 and 3, and Figures 1, 2 and 3, respectively. The shape, width, rake angle and spacing of the soil cutting tool strongly influenced soil disturbance and draft, in agreement with earlier studies (e.g., [10]). Overall, the chisel plow had lower draft per shank compared to the subsoiler, because of the relative depths at which both implements were operated [11], but there were no significant differences $(P<0.01)$ in total drawbar power (Table 2). However, a smoother soil surface and more uniform soil disturbance at depth was observed with the chisel compared with the subsoiler, which was due to the arrangement (spacing) and geometry of tines, and the relative depths of operation of both implements [10;13].

\section{Energy and power required for the subsoiling and chiseling operations, and soil cone index $(0-600 \mathrm{~mm})$ recorded after tillage}

\begin{tabular}{|c|c|c|c|c|c|}
\hline $\begin{array}{c}\text { Implement, depth } \\
\text { of operation }\end{array}$ & $\begin{array}{c}\text { Draft, } \\
\text { kN/shank }\end{array}$ & $\begin{array}{l}\text { Area distur- } \\
\text { bed, } \mathrm{cm}^{2}\end{array}$ & $\begin{array}{c}\text { Fuel cons- } \\
\text { umption, } l \cdot h^{-1}\end{array}$ & $\begin{array}{l}\text { Total drawbar } \\
\text { power, kW }\end{array}$ & $\begin{array}{c}\text { Cone index, } \\
\text { MPa }\end{array}$ \\
\hline Chisel, $280 \mathrm{~mm}$ & $3.75 a$ & $8534 a$ & $22.3 a$ & $66.7 a$ & $1.17 \pm 0.56 a$ \\
\hline Subsoiler, $450 \mathrm{~mm}$ & $6.65 b$ & $9594 b$ & $26.4 \mathrm{~b}$ & $68.3 a$ & $0.93 \pm 0.38 b$ \\
\hline
\end{tabular}

Different letters (vertically) indicate that values are significantly different. Use $P<0.01$, Duncan's multiple range test. Values of the cone index were significantly different from the zero-tillage control soil.

Field measurements of draft were in good agreement with the predicted draft as estimated by a single tine force prediction model ([11], Figure 1). Tines geometry and settings (shape, width, rake angle, spacing) strongly influenced the area disturbed by the tine as well as individual tine draft.

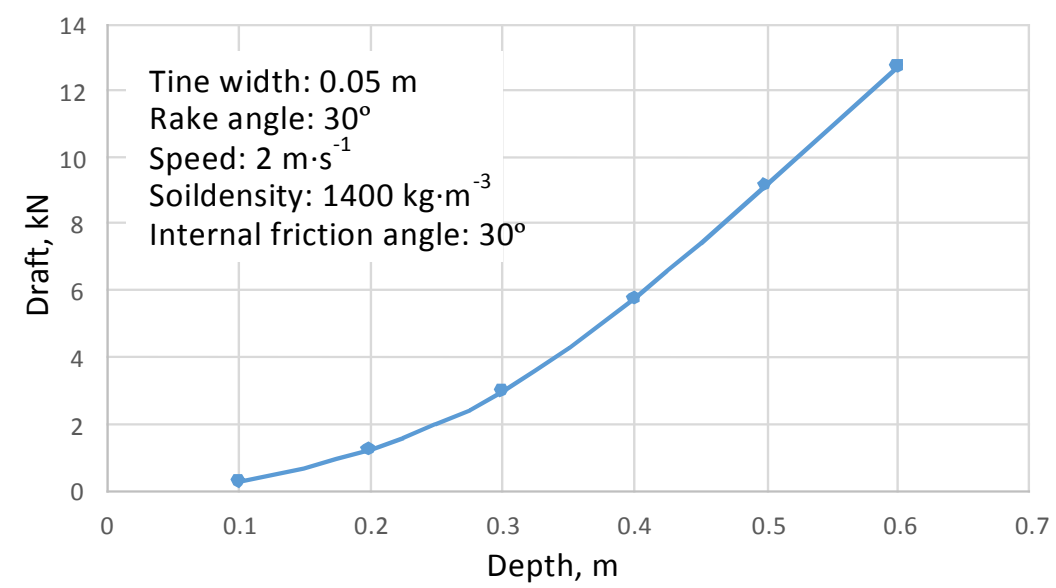

Fig. 1. Modelled draft $v s$. depth relationship for single tine implement operated on frictional soil using single tine force prediction model [11]

In the first and second crop seasons, the sunflower yields were approximately $28 \%$ and $19 \%$ higher in soil previously loosened with the subsoiler compared with the other treatments (Table 3). No significant differences in the sunflower yield were found between the chisel treatment and the unloosened control soil, but relative yield increases were $5.7 \%$ and $1.7 \%$ in the first and second crop seasons, respectively.

Table 3

Sunflower yield recorded over two growing seasons on unloosened soil (control), and after subsoiling or chiseling, respectively

\begin{tabular}{|l|c|c|c|}
\hline Tillage treatment & Unloosened soil & Subsoiler & Chisel \\
\hline Crop yield $\left(\mathrm{t} \mathrm{ha}^{-1}\right)$, harvest 2003 & $2.25 a$ & $2.87 b$ & $2.38 a$ \\
\hline Relative yield (\%) & --- & 27.5 & 5.7 \\
\hline Crop yield $\left(\mathrm{t} \mathrm{ha}^{-1}\right.$ ), harvest 2004 & $2.28 a$ & $2.72 b$ & $2.32 a$ \\
\hline Relative yield (\%) & --- & 19.2 & 1.7 \\
\hline
\end{tabular}

Different letters within each year (horizontally) indicate a significant difference between tillage treatments. Use $P<0.01$, Duncan's multiple range test. 


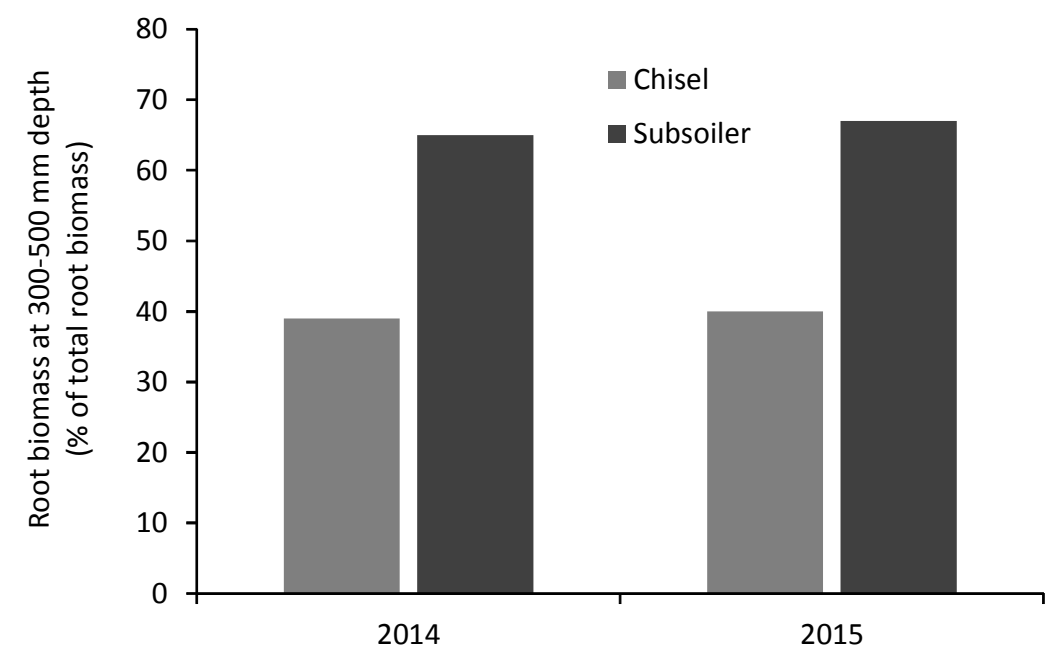

Fig. 2. Mean root biomass distribution in $300-500 \mathrm{~mm}$ depth interval relative to total root biomass for two deep tillage treatments measured 2.5 months after emergence over two cropping seasons

On average, the root biomass recorded in the subsoil and chisel treatments was 45 and $34 \mathrm{~g}$ of DM per plant, respectively, whereas in the unloosened (no-tillage) treatment this was $21 \mathrm{~g}$ of DM per plant. Root biomass was linearly correlated $\left(P<0.05, R^{2}=0.93\right)$ with the sunflower yield, and the yield also increased with increased soil depth available for root penetration (Figure 3).

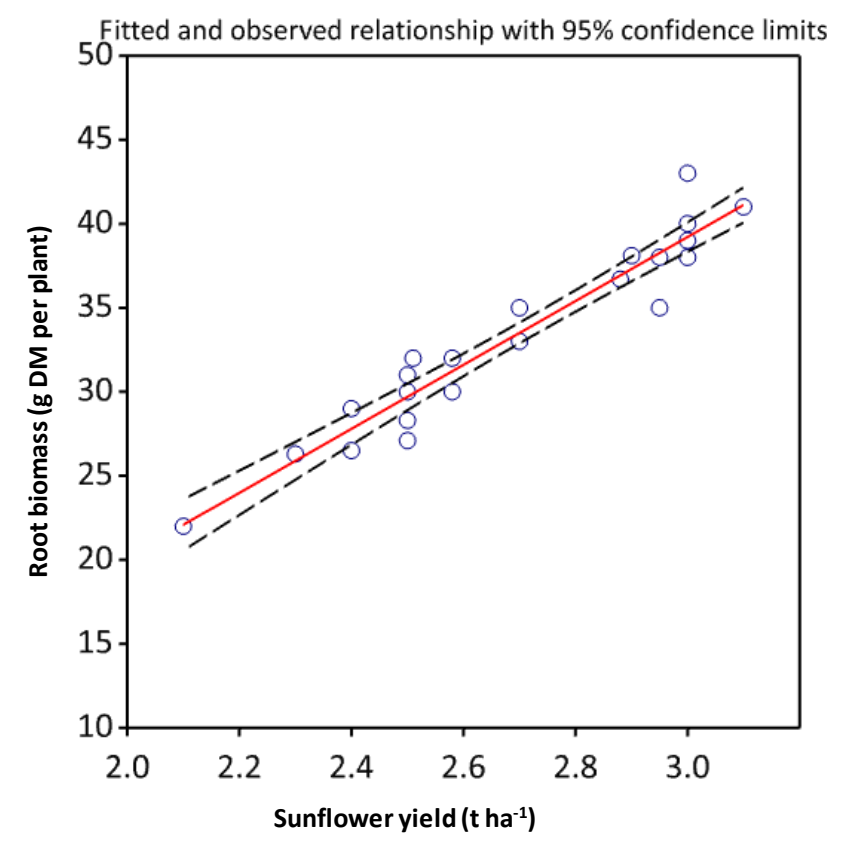

Fig. 3. Relationship between dry matter root biomass measured 45 days after emergence and grain yield for sunflower crops established at experimental site. Two curves on both sides of fitted line represent its $95 \%$ confidence interval

The beneficial effects of subsoiling and chiselling on removing soil compaction and reducing soil strength lasted for 2 years, and they became negligible after that time, when traffic intensity was greater than about $95 \mathrm{Mg} \cdot \mathrm{km}^{-1} \cdot \mathrm{ha}^{-1}$ due to re-compaction/re-consolidation of the soil profile, particularly in the 300-600 mm depth interval. Therefore, the frequency of subsoiling when CTF is not practiced should be every two years. From an agronomic perspective, the sunflower yield increased significantly in the first and second year of the experiment, concurrent with the effect of deep tillage. From an economic perspective, the yield of the crop in the first season was sufficiently high to pay-off the subsoiling operation, which cost between 18 and 52 USD per ha. In the second season, yield increments relative to the no-tillage treatment represented a net (average) profit of 12 USD per ha. 


\section{Conclusions}

The beneficial effects of subsoiling and chiselling on removing soil compaction and reducing soil strength to allow for improved root penetration lasted for 2 years, and they became negligible after that time, when traffic intensity was greater than about $95 \mathrm{Mg} \mathrm{km}^{-1} \mathrm{ha}^{-1}$. This was attributed to recompaction (by traffic) and natural re-consolidation of the soil profile, particularly in the $300-600 \mathrm{~mm}$ depth interval. Based on these observations, the frequency of subsoiling in this region when CTF is not practiced should be every two years. The sunflower yield increased significantly in the first and second year of the experiment, concurrent with the effect of the deep tillage operation. From an economic perspective, the crop yields attained in the first season after tillage operations were conducted paid-off the cost of the operation, which was between 18 and 52 USD per ha. In the second season, yield increases represented a net profit of 12 USD per ha relative to no-tillage. The tine geometry and settings (shape, width, rake angle, spacing) strongly influenced soil disturbance and draft. The chisel plow had lower fuel consumption and draft per shank than the subsoiler, but there were no significant differences in total drawbar power observed between the two implements. Despite the fact that total cross-sectional area loosened by the chisel plow was $14 \%$ more than the subsoiler, the efficiency of the chisel was $85 \%$ less than the subsoiler.

\section{References}

[1] Soane B. D., van Ouwerkerk C. Implications of soil compaction in crop production for the quality of the environment. Soil and Tillage Research, vol.: 35, issue: 1-2, 1995, pp. 5-22.

[2] Botta G. F, Tolón-Becerra A., Bienvenido F., Rivero et al. Sunflower (Helianthus annuus L.) harvest: Tractor and grain chaser traffic effects on soil compaction and crop yields. Land Degradation and Development, vol.: 29, issue: 12, 2018, pp. 4252-4261.

[3] Naderi-Boldaji M., Keller T. Degree of soil compactness is highly correlated with the soil physical quality Index $S$. Soil and Tillage Research, vol.: 159, 2016, pp. 41-46.

[4] Antille D. L., Chamen W. C. T., Tullberg J. N., Lal R. The potential of controlled traffic farming to mitigate greenhouse gas emissions and enhance carbon sequestration in arable land: A critical review. Transactions of the ASABE, vol.: 58, issue: 3, 2015, pp. 707-731.

[5] Antille D. L., Ansorge D., Dresser M. L., Godwin R. J. Soil displacement and soil bulk density changes as affected by tire size. Transactions of the ASABE, vol.: 56, issue: 5, 2013, pp. 1683-1693.

[6] Håkansson I., Reeder R. C. Subsoil compaction by vehicles with high axle load - Extent, persistence and crop response. Soil and Tillage Research, vol.: 29, issue: 2-3, 1994, pp. 277-304.

[7] Botta G.F., Tolón-Becerra A., Lastra-Bravo X., Tourn M., et al. Continuous application of direct sowing: Traffic effect on subsoil compaction and maize (Zea mays L.) yields in Argentinean Pampas. Soil and Tillage Research, vol.: 134, 2013, pp. 111-120.

[8] Dang Y. P., Balzer A., Crawford M., Rincon-Florez et al. Strategic tillage in conservation agricultural systems of north-eastern Australia: why, where, when and how? Environmental Science and Pollution Research, vol.: 25, issue: 2, 2018, pp. 1000-1015.

[9] Soil Survey Staff. Keys to soil taxonomy, $12^{\text {th }}$ Ed. USDA-Natural Resources Conservation Service, 2014. Washington DC, USA.

[10] Godwin R. J. A review of the effect of implement geometry on soil failure and implement forces. Soil and Tillage Research, vol.: 97, issue: 2, 2007, pp. 331-340.

[11] Godwin R.J., O’Dogherty M.J. Integrated soil tillage force prediction models. Journal of Terramechanics, vol.: 4, issue: 1, 2007, pp. 3-14.

[12] Sadras V.O., Calviño, P.A. Quantification of grain yield response to soil depth in soybean, maize, sunflower, and wheat. Agronomy Journal, vol.: 93, issue: 3, 2001, pp. 577-583.

[13] Spoor G., Godwin R.J. An experimental investigation into the deep loosening of soil by rigid tines. Journal of Agricultural Engineering Research, vol.: 23, issue: 3, 1978, pp. 243-258. 